\title{
Primum non nocere
}

Ved årsskiftet 1995/96 startet vi her i landet et offentlig program for mammografiscreening for kvinner i alderen 50-69 år. Målsettingen var å redusere brystkreftdødeligheten med $30 \%$ ved å oppdage sykdommen tidlig. Det var den gang liten bevissthet om overdiagnostikk av brystkreft.

Overdiagnostikk er diagnostisering av svulster som ikke ville ha gitt kvinnen symptomer i hennes levetid. Overdiagnostikk kan forekomme ved at det ved screening påvises svulster som ikke har potensial til å vokse (eller går i regress) eller ved at man påviser brystkreft hos kvinner som ville ha dødd før svulsten ville gitt symptomer. Det er forventet at brystkreftinsidensen stiger etter innføring av mammografiscreening, fordi man forskyver diagnosetidspunktet frem $i$ alder og tid. Hvis man antar at screening ikke fører til overdiagnostikk, vil man forvente at denne økte insidensen vil bli kompensert med et fall senere (1).

I dette nummer av Tidsskriftet presenterer Per-Henrik Zahl \& Jan Mæhlen en oppdatering av overdiagnostikk i det norske mammografiprogrammet (2). Forfatternes tidligere studie om overdiagnostikk ble kritisert for kort oppfølgingstid og for at de ikke hadde tatt hensyn til økende brystkreftinsidens av andre årsaker enn screening (bl.a. bruk av hormoner) (3-5). Dagens studie er en forbedring, idet de har tatt hensyn til kritikken. Zahl \& Mæhlen viser at om lag 800 kvinner hvert år får diagnostisert brystkreft (invasiv cancer eller duktalt carcinoma in situ) som ikke ville ha gitt dem plager og som de derfor ikke ville ha oppdaget dersom de ikke hadde gjennomgått screening. Men mens man altså har forventet at den økte forekomsten av brystkreft ved screening ville bli kompensert ved et insidensfall senere, finner Zahl \& Mæhlen ikke noe slikt fall. Konklusjonen må bli at det er betydelig overdiagnostikk ved mammografiscreening i Norge.

Det finnes flere typer av studiedesign man kan bruke for å beregne overdiagnostikk. Videre vil faktorer som påvirker forekomsten av brystkreft endre seg over tid. Hvordan man velger å ta hensyn til disse faktorene, vil påvirke estimatet for overdiagnostikk. Antallet kvinner som rammes av overdiagnostikk er derfor vanskelig å anslå helt presist. Etter 14 år med mammografiscreening er ikke den initiale økningen i brystkreft blitt fulgt av det forventede fallet - verken over tid eller hos kvinner i aldersgruppen der det ikke lenger screenes (over 70 år) $(2,3,6,7)$. Det er av underordnet betydning å få et helt presist anslag på antall overdiagnostiserte, det viktige er å innse at overdiagnostikk er et problem i brystkreftscreeningen (som i PSA-screeningen).

De som er overdiagnostisert, får skade kun fordi de har møtt til screening. De behandles unødig og utsettes for bivirkninger av behandlingen. Overdiagnostikk fører implisitt til overbehandling. Problemet kan bare løses ved bruk av screeningtester som kan skille mellom dødelige og ikke-dødelige svulster, men slike finnes ikke i dag. Problemet med overbehandling kan løses ved å endre behandlingen (8) eller ved å følge mindre aggressive svulster nøye uten å gi behandling «watchful waiting» (9). I mellomtiden må norske kvinner få balansert informasjon om fordeler og ulemper ved mammografiscreening. I dag formidles dessverre ikke ulempene like godt som fordelene.

Kreftregisteret, som driver mammografiprogrammet, overkommuniserer fordelene og underkommuniser ulempene i invitasjonsbrevet til kvinnene og på sine hjemmesider (10). Det fremheves bl.a. at delta- kelse i screening sikrer kvinner som får påvist brystkreft oppfølging ved et brystdiagnostisk senter. Imidlertid blir alle kvinner med brystkreft i Norge i dag fulgt opp ved brystdiagnostiske sentre, uansett om de har deltatt i screening eller ikke. Videre anføres det at deltakelse er i samfunnets interesse, da man kan overvåke helsetilbudet og drive forskning. Det å føre registre og forske bør imidlertid aldri være en grunn til å drive helsetilbud som screeningprogrammer. De som deltar i screening, forventer en fordel av det. Flere studier viser at kvinner overvurderer både sin egen risiko for å få brystkreft og effekten av mammografiscreening (11). Det er vesentlig at informasjonen om fordeler og ulemper ved screening er balansert.

Om vi baserer et anslag om overdiagnostikk på studien til Zahl \& Mæhlen, vil åtte kvinner være overdiagnostisert om 2500 kvinner inviteres til mammografiscreening. (800 overdiagnostiserte kvinner årlig, ca. 510000 kvinner som inviteres hvert annet år (800/ $(510000 / 2)) \cdot 2500=8)$.) Videre viser beregninger basert på data fra Norge at man må invitere 2500 kvinner for å redde én kvinne fra å dø av brystkreft $(12,13)$.

Primum non nocere - først, gjør ikke skade - må veies mot velgjørenhetsprinsippet. Gitt at vi påfører åtte kvinner en brystkreftdiagnose og forhindrer brystkreftdød hos én (mammografiscreening forhindrer ikke dødsfall hos kvinner) ved å invitere 2500 kvinner i Norge, da er det grunn til å være kritisk til mammografiscreening.

\section{Mette Kalager}

mkalager@hsph.harvard.edu

Mette Kalager (f. 1967) er lege, forsker ved Sykehuset Telemark og ved Harvard School of Public Health og tidligere leder for det norske mammografiprogrammet.

Ingen oppgitte interessekonflikter.

\section{Litteratur:}

1. Boer $\mathrm{R}$, Warmerdam $\mathrm{P}$, de Koning $\mathrm{H}$ et al. Extra incidence caused by mammographic screening. Lancet 1994; 343: 979.

2. Zahl PH, Mæhlen J. Overdiagnostikk av brystkreft etter 14 år med mammografiscreening. Tidsskr Nor Legeforen 2012: 132: 414-7.

3. Zahl PH, Mæhlen J. Overdiagnostisering ved mammografiscreening. Tidsskr Nor Lægeforen 2004; 124: 2238-9.

4. Langmark F, Thoresen S. Overdiagnostikk og mammografiscreening. Tidsskr Nor Lægeforen 2004; 124: 2800.

5. Njor S, Olsen AH, Lynge E. Overdiagnosticering eller forkert opgjørelsesmetode? Tidsskr Nor Lægeforen 2004; 124: 2800

6. Hofvind S, Sørum R, Haldosen T et al. Brystkreftforekomst før og etter innforing av mammografiscreening. Tidsskr Nor Lægeforen 2006; 126: 2935-8.

7. Hofvind S, Sakshaug S, Ursin G. Breast cancer incidence trends in Norway explained by hormone therapy or mammography screening? Int J Cancer 2011; e-publisert 5.7.

8. Zahl P-H, Gøtzsche PC, Mæhlen J. Natural history of breast cancers detected in the Swedish mammography screening programme: a cohort study. Lancet Oncol 2012: 12: 1118-1124

9. Kalager M. Regression of screening-detected breast cancer. Lancet Oncol 2011; 12: $1083-4$.

10. Kreftregisteret. www.kreftregisteret.no/no/Forebyggende/ Mammografiprogrammet/ (13.1.2012).

11. Domenighetti G, D'Avanzo B, Egger M et al. Women's perception of the benefits of mammography screening: population-based survey in four countries. Int J Epidemiol 2003; 32: 816-8.

12. Kalager $M$, Zelen $M$, Langmark $F$ et al. Effect of screening mammography on breast-cancer mortality in Norway. N Engl J Med 2010; 363: 1203-10.

13. Welch HG. Screening mammography - a long run for a short slide? N Engl $J$ Med 2010; 363: 1276-8 